\title{
Television for Agricultural Extension in Nepal
}

\section{S Rijal ${ }^{1}$ and Y Devkota ${ }^{2 *}$}

${ }^{1}$ Faculty of Agriculture, Agriculture and Forestry University, Rampur, Chitwan, Nepal

${ }^{2}$ Institute of Agriculture and Animal Science, Paklihawa, Rupandehi, Nepal

*Corresponding Author: Y Devkota, Institute of Agriculture and Animal Science, Paklihawa, Nepal.

Received: July 08, 2019; Published: August 08, 2019

DOI: 10.31080/ASAG.2019.03.0605

The word "extension " has been derived from Latin language "Ex" meaning out and "tension" meaning stretch out. Extension means to disseminate useful information or ideas. The concept of extension education is much more important in community development. Agriculture is more related with development. So Agricultural extension is necessary for community development. Agricultural extension is a special branch of extension education which deals with various aspects. Agricultural extension is an informal out of school education which assisting the rural people to bring changes.

Agricultural extension requires the approach as its essence. There are practices of various extensional education methods such as Individual, Group and Mass methods. The extension teaching methods are categorized according to use and according to form which are listed below:

\begin{tabular}{|l|c|c|}
\hline \multicolumn{1}{|c|}{$\begin{array}{c}\text { Individual } \\
\text { contact }\end{array}$} & Group contact & Mass contact \\
\hline Field visits & Result demonstration & Pamphlet, poster \\
\hline Office calls & Method demonstration & Bulletin, leaflets \\
\hline Personal letters & Mini-kit trail & Newspaper \\
\hline telephone calls & $\begin{array}{c}\text { Meeting, conference, } \\
\text { lecture }\end{array}$ & Circular letters \\
\hline & Seminar, panel discussion & Television \\
\hline & $\begin{array}{c}\text { Workshops, Forum, Buzz } \\
\text { session }\end{array}$ & Radio \\
\hline & Extension talk & Exhibition, Fair \\
\hline
\end{tabular}

Table a

And according to form it is in written (Bulletins, circular letters, personal letters, leaflets, News article), Spoken (official calls, telephone calls, meetings, field visits) and visual (Result demonstration, posters, movies motion picture, slides, charts etc) [1]. Among above Television is one of the Audio-visual type of method which has benefits of radio, newspaper and motion pictures. Opportunity for audience to see things is advantage of Television (TV) over radio. Television is more effective, powerful from educational viewpoint but cost and expenditure of it is more than that of radio [2].

Nepal Television (NTV) which started its service in 1984 has been telecasting 15 minute programme since 1996 at evening time (6.40-6.55 pm).

\begin{tabular}{|l|c|}
\hline \multicolumn{1}{|c|}{ Days } & Activity \\
\hline Sunday & Farmers interaction \\
\hline Monday & New Agricultural activity \\
\hline Tuesday & Experts with farmers \\
\hline Wednesday & Success story \\
\hline Thursday & Farmers concern \\
\hline Friday & Weekly agricultural Activities \\
\hline Saturday & Agricultural Tele-serial \\
\hline
\end{tabular}

Table b

Source: [3]

Among above various program it was found that Saturday programmed is best and people prefer more information presented in dramatic form and moreover it concluded that TV plays important role in dissemination of agriculture information [4].

Also, [2] finds that significant knowledge enhancement from 3.73 to 6.26 through a TV program and educational contents of TV program are emphasized on fighting against pests and correct method of using agricultural poisons. In Nepal, the extension service coverage is only $15 \%$ [3]. There is a large gap exist between extension agent and farmers. So, Television tends to solve this problem by providing effective communication. As we know that Nepalese agriculture are in infant stage in aspect of technological advancement and growth. 


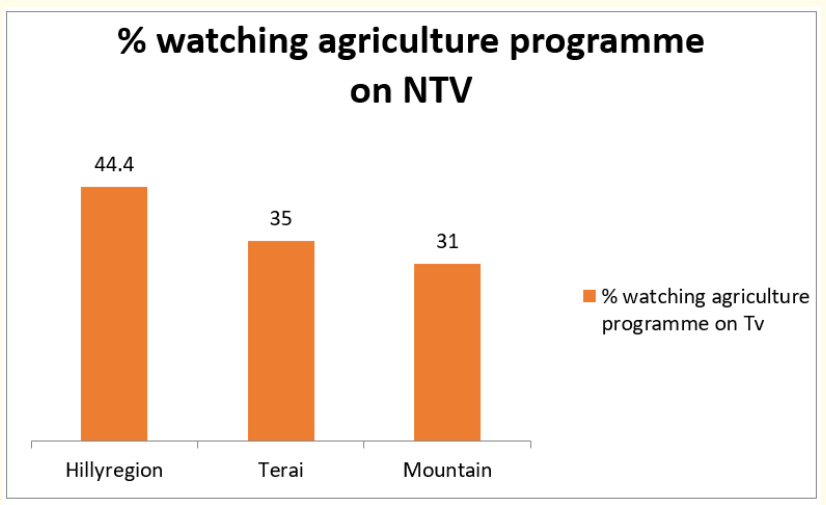

Figure 1

Source: [5]

Majority of Nepalese youth are in foreign country in search for employment and here no respect for agricultural profession. Commercialization, Mechanization and proper agro-communication is necessary to way forward the Nepalese agriculture. It is possible only by providing proper information and knowledge of modern agriculture to rural farmers. In this context Television is trying to reach maximum farmer through agricultural education and entertainment. Agriculture related program like Krishi karyakarm, krishi samachar and agriculture television are involved to reach, educate, motivate and finally to make the nation prosperous. Several other private television programs and Agriculture television network private limited are involved to remove lack of knowledge and information of rural farmers.

\section{Scope and role}

The variation in geographical condition and climate definitely result in production of various products. Through television channel newer possibility are providing to farmers like Organic farming, mulching, Integrated pest management, Nutrient management, water conservation etc. In Nepal newer probable possibility of cultivation like possibility of organic production of Dragon fruit in upper marginal belt [6] Conservation farming in Garlic and various others crop [7] and many more. Television can play an effective role for agricultural technology transfer among farming community and able to disseminate information easily to large audience. Youth are becoming more interested in agriculture through TV shows when stories of farmers represents as in Superheroes which entertains and at the same time educational, hence the term 'edutainment'. Edutainment reaches out to a much wider audience, creating passion for agricultural farming, delivering information on new technologies to farmers [8].

\begin{tabular}{|l|}
\hline $\begin{array}{l}\text { Change in people's knowledge and attitudes towards agricul- } \\
\text { ture }\end{array}$ \\
\hline Change Farming behavior \\
\hline Link people to services to obtain help and support \\
\hline Impact on the social and political environment \\
\hline $\begin{array}{l}\text { Stimulate public discussion and debate about improved prac- } \\
\text { tices }\end{array}$ \\
\hline Stimulate social action on particular issues \\
\hline Influence and effect policy change \\
\hline
\end{tabular}

Table 1: Impact of Edutainment.

Source: [8]

Television needs to support following emerging issues of Nepal.

\begin{tabular}{|l|c|}
\hline \multicolumn{1}{|c|}{ Topic } & References \\
\hline $\begin{array}{l}\text { Implementation of biodiversity strategy and plan- } \\
\text { ning as Nepal faces various emerging Challenges in } \\
\text { biodiversity conservation }\end{array}$ & [9] \\
\hline $\begin{array}{l}\text { Medicinal and aromatic plants (MAPs), its impor- } \\
\text { tance, uses, important export sector for Nepal in } \\
\text { terms of employment, Revenue generation, em- } \\
\text { ployment, social impact and poverty alleviation. }\end{array}$ & \\
\hline $\begin{array}{l}\text { Various climate smart agriculture adaptation and } \\
\text { Climate Smart village (CSV) practices in Nepal }\end{array}$ & \\
\hline $\begin{array}{l}\text { Focused on Fertilizers problem in Nepal on rural } \\
\text { areas }\end{array}$ & {$[11]$} \\
\hline $\begin{array}{l}\text { Focused on Agricultural marketing problems in } \\
\text { Nepal: Problem of transportation, Lack of storage, }\end{array}$ & \\
Lack of promotional activities, lack of technical \\
knowledge, Defective measuring equipment, lack \\
of organized market
\end{tabular}

Table 2: Television needs to support following emerging issues of Nepal. 
In this way, Television play vital role in agricultural extension in Nepal.

\section{Bibliography}

1. Agropedia. Extension-teaching methods (2012).

2. Nazari M and Hassa S. "The role of television in the enhancement of farmers' agricultural knowledge”. African Journal of Agricultural Research 6.4 (2011): 931-936.

3. MoAD. Krishi Diary. Lalitpur, Nepal: Agriculture Information and Communication Centre (AICC) (2076).

4. Kandel G., et al. "Study of Tv Programme in Disseminating Agricultural information by Ecological region of Nepal". Journal of Global Communication 9.1 (2016): 52-55.

5. NDRI. Report on Impact Assessment of effectiveness of AICC's communication sources in Agriculture in Western Nepal. Lalitpur: Agriculture Information and Communication Centre (AICC) (2015).

6. Rijal S. "Dragon fruit: Fruit for future Nepal”. Acta Scientific Agriculture 3.7 (2019): 153-154.

7. Rijal S. "Conservation farming in Garlic". Acta Scientific Agriculture 3.7 (2019): 98.

8. Gfras. (n.d.). Global Good Practices in Rural Advisory Services Intiative. Retrieved from Edutainment TV for disseminating information about agriculture.

9. Bhuju RU., et al. Nepal Biodiversity Resource Book. Kathmandu: International Centre for Integrated Mountain Development (ICIMOD) and GoN (2007).

10. JABAN. Medicinal and Arromatic Plants (MAPs) Stakeholders Directory. Jadibuti Association of Nepal (JABAN) (2015).

11. Rijal S and Rijal B. "Climate Smart Agriculture Concept and Adaptation in Nepal: An Overview". International Journal of Research and Review 6.1 (2019): 47-56.

12. Poudel A. Rural farmers travel to kathmandu for fertilizers only to return empty handed. Kathmandu: The Kathmandu post (2019).

13. https://www.kullabs.com/classes/subjects/units/lessons/ notes/note-detail/7999

14. FAO. FAO Success Stories in Nepal (2007).

Volume 3 Issue 9 Sepetember 2019

(C) All rights are reserved by S Rijal and Y Devkota. 